\title{
Conscious Parallelism and Price Fixing: Defining the Boundary
}

Section 1 of the Sherman Antitrust Act $^{1}$ has eliminated most overt price-fixing arrangements. In order to avoid sanctions under this law, firms wishing to engage in collusive, ${ }^{2}$ anticompetitive practices are forced to enter into secret agreements to fix prices. ${ }^{3}$ The detection of these covert agreements has become the central focus of section 1 enforcement. ${ }^{4}$ Direct evidence of such agreements is difficult to obtain, however, and courts must often rely on indirect or circumstantial evidence of conspiracies to fix prices. Frequently, an important factor in establishing the existence of such a conspiracy is similar conduct by rival firms that suggests they are attempting to set prices or carve up the market for a particular product. ${ }^{.}$Such "conscious parallelism" by itself does not constitute concerted action in violation of the Sherman Act, ${ }^{6}$ however, and courts have disagreed over what additional evidence ("plus factors") must be produced in order to permit a trier of fact to infer the existence of a price-fixing agreement.

1 "Every contract, combination in the form of trust or otherwise, or conspiracy, in restraint of trade or commerce among the several States, or with foreign nations, is declared to be illegal." 15 U.S.C. § 1 (1982).

2 Professor, now Judge, Richard Posner noted the difference between a cartel and a collusive arrangement: "Although sometimes the term 'cartel' is used to refer to any collusive arrangement, it is more often limited to the kind of formal, above-board agreement among firms to limit their competition that one finds in markets, here and abroad, not subject to the Sherman Act." Richard Posner, Antitrust Law: An Economic Perspective 39 (1976). The most notable example of an overt cartel is the Organization of Petroleum Exporting Countries (OPEC).

S Posner, Oligopolistic Pricing Suits, the Sherman Act, and Economic Welfare: A Reply to Professor Markovits, 28 Stan. L. Rev. 903, 904 (1970).

4 Posner argues that this focus has "virtually emptied [the rule against price fixing] of any economic content, to become in effect a branch of the criminal law of conspiracies and attempts." Id.

- See Delaware Valley Marine Supply Co. v. American Tobacco Co., 297 F.2d 199, 202 (3d Cir. 1961), cert. denied, 369 U.S. 839 (1962).

- See, e.g., Theatre Enters., Inc. v. Paramount Film Distrib. Corp., 346 U.S. 537, 541 (1954).

7 Compare In re Plywood Antitrust Litig., 655 F.2d 627, 634, 637 (5th Cir. 1981) (allowing the inference of conspiracy from parallel conduct and evidence of opportunity to conspire), cert. dismissed sub nom. Lyman Lamb v. Weyerhauser, 462 U.S. 1125 (1983), with Weit v. Continental Ill. Nat'l Bank \& Trust Co., 641 F.2d 457, 463 (7th Cir. 1981) (holding that parallel conduct plus opportunity to conspire did not permit the inference of 
The plus factor most often considered by courts in determining whether parallel behavior is the result of an agreement is the business-justifications test. Under this test, a price-fixing agreement may be inferred from parallel conduct if firms cannot show legitimate independent business reasons for engaging in such practices. ${ }^{8}$ Once conscious parallelism sufficient to establish an agreement has been found; the practices are deemed illegal per se, without an inquiry into whether the practices are actually anticompetitive. $^{9}$

Commentators, on the other hand, including Richard Posner and Donald Turner, have argued that the courts' emphasis on establishing the existence of an agreement is improper..$^{10}$ Although Posner and Turner employ different economic analyses, both conclude that parallel practices violate the Sherman Act if, and only if, they have anticompetitive effects. ${ }^{11}$ Both advocate an inquiry-similar to the rule of reason ${ }^{12}$-into the economic effects of firms' parallel behavior without a separate inquiry into the existence of an agreement among firms not to compete. ${ }^{13}$

This comment argues that both the courts' treatment of inferred agreements as per se illegal and Posner's and Turner's ruleof-reason inquiries for anticompetitive effects are inadequate and contrary to section 1, which requires that there be both an agreement and a restraint of trade. ${ }^{14}$ Part I of the comment examines the economics of cartelization and conspiracies to restrain trade and outlines the differing approaches to the subject suggested by Turner and Posner. Part II explores the judicial treatment of parallel behavior.

In Part III, the comment argues that findings of both an

conspiracy when rebutted by evidence that the adoption of the parallel conduct was supported by independent business justifications), cert. denied, 455 U.S. 988 (1982).

- See infra note 82 and accompanying text.

- See, e.g., In re Japanese Elec. Prods. Antitrust Litig., 723 F.2d 238, 310 (3d Cir. 1983), cert. granted sub nom. Matsushita Elec. Indus. Co. v. Zenith Radio Corp., $105 \mathrm{~S}$. Ct. 1863 (1985); Weit v. Continental Ill. Nat'l Bank \& Trust Co., 641 F.2d 457, 465 (7th Cir. 1981), cert. denied, 455 U.S. 988 (1982); In re Plywood Antitrust Litig., 655 F.2d 627 (5th Cir. 1981), cert. dismissed sub nom. Lyman Lamb v. Weyerhauser, 462 U.S. 1125 (1983). But see Ambook Enters. v. Time Inc., 612 F.2d 604, 618 n.23 (2d Cir. 1979) (questioning the parties' assumption that per se rule applied), cert. dismissed, 448 U.S. 914 (1980).

${ }^{10}$ See infra notes $44-48,55-57$ and accompanying text.

11 See infra notes 34-66 and accompanying text.

12 Under the rule of reason, a court must find that a practice is anticompetitive in effect before it condemns the practice under the Sherman Act. See infra note 70 and accompanying text.

13 See infra note 66 and accompanying text.

14 See supra note 1. 
agreement and anticompetitive conduct are required in order to establish a violation of section 1 . Thus, parallel conduct found to constitute an agreement under the business-justifications test should not be treated as per se illegal because, unlike many overt price-fixing agreements, such conduct is not anticompetitive on its face. Conversely, condemning parallel activity under a rule of reason inquiry without regard to the existence of an agreement exposes firms to liability for otherwise legitimate conduct solely because the conduct has an adverse impact on competition. Under such a standard, firms would be liable under section 1 not because their conduct, standing alone, is anticompetitive, but because the interaction of the conduct of several firms has an adverse impact on competition. Such an effect cannot properly be brought within the scope of section 1 . In order to find a violation of section 1 , therefore, courts should first determine, using the business-justifications test, whether there is an agreement, and should then analyze the parallel conduct under the rule-of-reason inquiry to determine whether the practices have anticompetitive effects.

\section{Economic Approaches to Cartels, Conspiracies, and Conscious Parallelism}

In a competitive market, no firm acting alone can affect the market price of a commodity. ${ }^{15}$ Firms act as price-takers and maximize profits by increasing their output until the cost of the last unit sold (the marginal cost of production) equals the market price. ${ }^{16}$ By forming a cartel, however, firms can affect the market price. ${ }^{17}$ Cartels maximize the profits of their members by reducing total output and setting prices well above marginal cost, ${ }^{18}$ thus achieving a market price that is higher than the price that would prevail if the market were competitive. ${ }^{19}$

15 Edwin Mansfield, Microeconomics 20 n.2 (3d ed. 1979).

16 R. Posner, supra note 2, at 241.

17 R. Posner \& F. Easterbrook, Antitrust: Cases, Economic Notes, and Other Materials 1065 (2d ed. 1981).

18 See James Koch, Industrial Organization and Prices 420-22 (2d ed. 1980).

19 R. POSNER \& F. EASTERBROOK, supra note 17, at 1064-65. The probability of effective collusion is not the same for all markets. Several market factors have been identified that facilitate collusion; these include product homogeneity, inelastic product demand, concentration of economic power, fewness of firms, and the conviviality of interfirm relationships. See, e.g., F.M. Scherer, Industrial Market Structure and Economic Performance 199227 (2d ed. 1980); Hay \& Kelley, An Empirical Survey of Price Fixing Conspiracies, 17 J.L. \& Econ. 13, 14-16 (1974). The Depression-era cigarette industry presents a good example of a market ripe for collusion. It was concentrated and dominated by three powerful manufacturers. Moreover, the "Big Three" had cozy business relations. For example, in order to 
The monopoly prices ${ }^{20}$ resulting from cartelization have two principal effects. First, wealth is redistributed from consumers to participants in the price-fixing arrangement. ${ }^{21}$ While this outcome is normatively neutral from an economic perspective, ${ }^{22}$ it is undesirable if society favors consumers over producers. Second, monopoly prices reduce the quantity of the good supplied because some purchasers, facing a higher price, buy less desirable substitute products. ${ }^{23}$ These consumers are thus worse off to the extent that the substitute is inferior to the monopolized good, while producers are better off, despite the foregone sales, only because they collect monopoly profits. ${ }^{24}$ The resulting inefficient utilization of resources represents a deadweight loss to society. ${ }^{25}$

Formal cartels are inherently unstable. Members have an incentive to cheat on the cartel by pricing below the monopoly price. By reducing price, a member can capture profits at the expense of other members, so long as the rest of the cartel adheres to the monopoly price. ${ }^{28}$ Cartels must therefore develop enforcement mechanisms that protect against such cheating; detection of cheating and enforcement of the cartel price are likely to be imperfect, however, if there are many member firms or if information about market transactions is difficult to obtain. ${ }^{27}$ Cheating tends eventually to drive cartel prices back to the competitive level.

Many economists suggest, however, that in an oligopolistic

keep production costs down, each refrained from buying raw tobacco grades in which others had a special interest. Thus, even during a period of falling demand, the three, apparently through very informal collusion, were able to earn high profits. See American Tobacco Co. v. United States, 328 U.S. 781, 798-808 (1946).

${ }^{20}$ The monopoly price is determined by finding the point at which the cartel marginal cost curve (the horizontal sum of the marginal cost curves of the individual firms, if input prices do not increase as the cartel is formed) intersects with the market marginal revenue curve. The price along the demand curve at that output level is the joint-maximizing or monopoly price. E. MANSFiELD, supra note 15 , at 347-48.

${ }^{21}$ See R. Posner \& F. EASTERBrook, supra note 17, at 4-11; F. Scherer, supra note 19, at 14-20.

22 The conclusion of neutrality assumes that everyone places the same value on the last additional dollar received or spent. Posner argues that monopoly profits will also be converted into social costs, i.e., deadweight loss, because a firm will expend real resources in order to become a monopolist or gain admission to a cartel. Through this "competitive" process, firms might spend resources just equal at the margin to the amount of expected monopoly profits. R. POSNER, supra note 2, at 11-12.

${ }^{23} \mathrm{Id}$. at 242.

24 Id.

${ }^{23}$ For a general discussion, see J. КосH, supra note 18 , at 72-81.

28 Id. at $420-22$.

${ }^{27}$ George Stigler, A Theory of Oligopoly, in The Organization of Industry $42-43$ (2d ed. 1983). 
market-one that has only a few producers-a formal agreement is not necessary for rival firms to set a monopoly price, or at least a price that is significantly greater than the competitive level. ${ }^{28}$ Even though a market may consist of several firms, each may realize that its business decisions interact with those made by other firms. ${ }^{28}$ One variant of this interdependence theory-known as monopolistic competition-suggests that firms fully recognize the implications of interdependence and realize that they need not be passive price-takers. ${ }^{30}$ As a result, they will set prices at the monopoly level, knowing that price cuts will merely erode industry, and hence individual, profits. ${ }^{31}$

The theory of monopolistic competition has profound implications for section 1 enforcement. It suggests that firms, merely by recognizing their interdependence and without the need for formal agreement, may achieve the prohibited ends of a formal cartel. ${ }^{32}$ Since much of American industry conforms to the oligopoly model, present antitrust law thus may be incapable of dealing with a pervasive market problem. ${ }^{33}$

Professor Donald Turner, embracing the theory of monopolistic competition, has argued that oligopolists who achieve a monopoly price by considering the probable reaction of others in the market, and "without more in the way of 'agreement' than is found in 'conscious parallelism,' should not be held unlawful conspirators

28 Peter Asch, Industrial Organization and Antitrust Policy 41-70 (rev. ed. 1983). 29 Id.

30 Id. at 59. Edward Chamberlin, the first proponent of this theory, observed that: [f]or one competitor to take into account the alterations of policy which he forces upon the other is simply for him to consider the indirect consequences of his own acts. Let each seller, then, in seeking to maximize his profit, reflect well, and look to the total consequences of his move. He must consider not merely what his competitor is doing now, but also what he will be forced to do in the light of the change which he himself is contemplating.

Edward Chamberlin, The Theory of Monopolistic Competition 47 (8th ed. 1962) (footnote omitted).

${ }^{31} \mathrm{P}$. Asch, supra note 28, at 59. Only "when the individual's influence upon the price becomes so small that he neglects it" will price fall to the competitive level. E. Chamberin, supra note 30 , at 48 .

${ }^{32}$ As Chamberlin explained:

This interdependence must, however, be interpreted with care, for, in the nature of the case, when there are only two or a few sellers, their fortunes are not independent. There can be no actual, or tacit, agreement-that is all. Each is forced by the situation itself to take into account the policy of his rival in determining his own, and this cannot be construed as a "tacit agreement" between the two.

E. Chamberlin, supra note 30 , at $\mathbf{3 1}$ (second emphasis added).

${ }^{33}$ See Rahl, Conspiracy and the Anti-Trust Laws, 44 ILL. L. Rev. 743, 755 (1950). 
under the Sherman Act."34 Turner, reflecting the general approach of the "Harvard School,"35 notes that "[a]s a legal conclusion, this could be stated in either of two ways: (1) there is no violation because there is no 'agreement;' or (2) there is no violation because, although there is 'agreement,' the agreement cannot properly be called an unlawful agreement."

From this premise, Turner concludes that parallel conduct only indicates illegal behavior if all of the firms' conduct cannot be explained by consciously parallel behavior and oligopoly pricing. ${ }^{37}$ Turner would not, for example, condemn pure parallel-pricing activity (e.g., price leadership), ${ }^{38}$ but he would proscribe the adoption of "rigid zone pricing" (e.g., a delivered-price scheme). ${ }^{39}$ In part, this distinction rests on a prudential argument that to attack "natural" oligopolistic pricing behavior would require the courts to engage in regulatory "rate-setting" functions;" "artificial" pricing structures, by contrast, can be remedied simply by an injunction. ${ }^{41}$ The distinction also rests on the belief "that oligopoly price behavior can be described as individual behavior-rational individual decisions in the light of relevant economic facts-as well as it can be described by "agreement." "42 These "relevant economic facts" include the likely response of other oligopolists to a competitor's pricing decisions. ${ }^{43}$

Turner suggests that parallel behavior should not be charac-

34 Turner, The Definition of Agreement Under the Sherman Act: Conscious Parallelism and Refusals To Deal, 75 HARv. L. REv. 655, 671 (1962).

33 See, e.g., Lawrence Sullivan, Handbook of the Law of Antitrust 359 (1977); Rahl, supra note 33 , at $755-56$.

so Turner, supra note 34 , at 671 .

37 Id. at 672.

ss Id. at 681 .

s9 Id. at 673-75. Under a delivered-price system, a uniform price is charged each buyer regardless of the distance from the production source. F. SCHERER, supra note 19, at 326; see also infra notes 129-30 and accompanying text.

10 If, for example, defendants were convicted of price fixing based only on evidence of parallel-pricing practices, the court could not effectively enjoin an "agreement" because, under Turner's view of economics, the parties priced in a "profit-maximizing" way given all the factors in the market. Turner, supra note 34 , at 666. An injunction, to be effective, would necessarily tell defendants: "Always increase your output to the point where marginal cost . . . equals the price that can be obtained; or alternatively, always lower your price to the point where it equals marginal cost." "Id. at 670. In order to eliminate monopoly profits, the court's analysis would have to "closely resemble what in theory is imposed by public-utility regulation," causing immense practical problems for the courts. Id.

41 Id. at 666.

12 Id.

is Id. at 673 . 
terized as an agreement prohibited under section $1 ; 44$ rather, oligopolistic pricing is more appropriately attacked as a violation of the prohibition in section $2^{45}$ of monopolization or attempts to monopolize, which does not require proof of an agreement. ${ }^{46} \mathrm{~A}$ parallel practice should thus be condemned only if it "protects or augments market power or extends it into other markets." ${ }^{47}$ Such treatment of parallel behavior would achieve what Turner considers to be the important goal of bringing "the law on oligopolists' conduct more or less in line with the law on monopolists' conduct."48

Professor, now Judge, Richard Posner has suggested a different approach to conscious parallelism, reflecting the views of "Chicago School" economists on oligopoly theory. Posner states that "[t]he relationship between the level of concentration in a market and the probability that pricing in that market will be noncompetitive can be elucidated in simpler and more fruitful terms than interdependence: in terms of the theory of cartels." ${ }^{49} \mathrm{He}$ suggests that absent agreement, firms, even in an oligopolistic market, will act as rivals and set price and output at competitive rather than monopoly levels. ${ }^{50}$ Under this view, oligopoly is a necessary, but not sufficient, condition for successful price fixing. ${ }^{51}$ From this basic premise, Posner argues that "voluntary actions by the sellers are necessary to translate the bare condition of an oligopoly market into a situation of noncompetitive pricing." ${ }^{52}$ Such voluntary action, whether in the form of express or tacit collusion, constitutes concerted action and thus falls within the ambit of section $1 .^{.3}$ Posner also argues that parallel behavior can be useful circumstantial evidence of a formal, but concealed, cartel. When the actions of a

"Turner also suggests defining "agreement" under the Sherman Act in terms of "interdependence of decisions" because the courts have gone "beyond the boundaries of explicit, verbally communicated assent to a common course of action." Id. at 683.

1515 U.S.C. $\$ 2$ (1982) (making it illegal to "monopolize, or attempt to monopolize, or combine or conspire . . . to monopolize any part of . . trade or commerce").

48 Turner, supra note 34, at 682; see also Note, Conscious Parallelism and the Sherman Act: An Analysis and a Proposal, 30 VAND. L. REv. 1227, 1241 (1977) ("[C]onscious parallelism among the largest firms in a highly concentrated industry shall constitute prima facie evidence of a [Sherman Act \$ 2] conspiracy to monopolize.").

47 Turner, supra note 34 , at 682 .

48 Id.

49 Posner, Oligopoly and the Antitrust Laws: A Suggested Approach, 21 STan. L. Rev. 1562, 1569 (1969) (footnote omitted).

so Id. at 1566-69.

s1 Id. at 1571-74.

${ }^{82} \mathrm{Id}$. at 1575 .

${ }^{83}$ Id. at 1576-78. 
formal cartel are completely concealed, however, the observable behavior of the cartel's members is consistent with a hypothesis of tacit collusion. Thus, a submerged cartel should be treated as a form of tacit collusion. ${ }^{54}$

In Posner's view, the "biggest problem in applying section 1 . . . to tacit collusion is that of proof: How can the existence of noncompetitive pricing be established without any proof of acts of agreement, implementation, or enforcement?"ss He suggests a twostep approach to this evidentiary problem: first, economic evidence should be examined to identify "markets in which conditions are propitious for the emergence of collusion"; second, market evidence should be examined to determine whether collusion in fact exists. ${ }^{56}$ This technique would avoid the need for extensive, costly searches for "hot-document" evidence of agreement-what he calls the "cops-and-robbers' approach to price-fixing that has heretofore dominated the law.""s?

One drawback in Posner's two-step approach is that it would require a "ramble through the wilds of economic theory" case. Once parallel conduct is shown, litigants would be required to produce massive and often ambiguous economic evidence and to spend large sums on expert interpretation of such evidence. ${ }^{59}$

st Id. at 1575 .

ss Id. at 1578.

st R. PoSNER, supra note 2, at 55. Conditions favorable to collusion include: (1) concentration of sellers; (2) lack of a fringe of small sellers; (3) inelastic demand at the competitive price; (4) lengthy time required for new entry into the market; (5) many customers; (6) a standardized product; (7) the principal firms sell at the same level in the chain of distribution; (8) emphasis on price competition over other forms of competition; (9) a high ratio of fixed to variable costs of production; (10) static or declining demand over time; (11) award of business on the basis of sealed bids; (12) a poor antitrust record for the industry. $I d$. at $55-62$.

Evidence of collusive behavior includes: (1) fixed relative market shares; (2) price discrimination; (3) exchanges of price information; (4) regional price variations; (5) identical bids; (6) price, output, and capacity changes at the formation of a cartel; (7) industry-wide resale price maintenance; (8) declining market shares of leaders; (9) high amplitude and fluctuation of price changes; (10) elastic demand at the market price; (11) consistent levels and patterns of profits; (12) basing-point pricing. Id. at 62-71.

Proving agreement by the use of economic evidence is also discussed in Kamerschen, An Economic Approach to the Detection and Proof of Collusion, 17 AM. Bus. L.J. 193 (1979); Markovits, Oligopolistic Pricing Suits, the Sherman Act, and Economic Welfare (pt. 3), 27 Stan. L. Rev. 307 (1975); Comment, A Structural Approach to the Application of Section One of the Sherman Act to Oligopolistic Interdependence, $35 \mathrm{ME}$. L. REv. 181 (1983).

${ }^{87} \mathrm{R}$. POSNER, supra note 2 , at 47.

s8 This description of economic analysis in antitrust courtrooms is found in United States v. Topco Assocs., 405 U.S. 596, 610 n.10 (1972).

B8 Posner himself accepts the proposition that economic evidence "frequently is ambig- 
Moreover, because Posner would retain the rule of per se illegality for overt acts of conspiracy, ${ }^{60}$ it is unlikely that plaintiffs would abandon all efforts to uncover "smoking gun" evidence. Thus, it is not clear that judicial economy would be enhanced under this twostep approach. Posner's position may also be criticized on the ground that it might condemn, under section 1 , firms that have achieved a monopoly market price merely by considering their rivals' behavior in setting prices-a result that Turner finds both contrary to the statute and unsound as a policy matter. ${ }^{61}$

Posner argues, however, that a firm that raises price and restricts output, with the mere expectation that other firms will do the same, engages in a form of concerted action analogous to a unilateral contract. ${ }^{62} \mathrm{He}$ admits that, if pressed too far, this approach might condemn firms that do not in fact engage in anticompetitive conduct-for example, those firms that consider the probable response of competitors in setting prices after a common cost increase. ${ }^{63}$ Thus, Posner concludes that "the law should not always equate tacit and explicit pricing agreements." ${ }^{64}$ Tacit agreement is objectionable and should be condemned only when its effect is to limit output and raise prices above the competitive level. ${ }^{65}$

uous." Posner, supra note 3 , at 910.

${ }^{\circ 0}$ R. PoSNER, supra note 2, at 76. Posner states that he would apply this rule at least in markets "that exhibit the predisposing characteristics toward collusion." Id.

${ }^{61}$ Posner summarized his understanding of the differences between the Harvard and Chicago Schools of antitrust in Posner, The Chicago School of Antitrust Analysis, $127 \mathrm{U}$. PA. L. REv. 925 (1979). He notes that while each accepts the conclusion, found in many studies, that there is a positive correlation between concentration and profitability in an industry, the two schools diverge over the reason for this correlation and thus over the appropriate legal response. Id. at 944. The Harvard School, Posner writes, "contends that the correlation is explained by the fact that the leading firms in highly concentrated industries employ 'conscious parallelism' to avoid price competition and thereby earn abnormal profits." Id. The Harvard School's response to this problem is to seek deconcentration of these industries by breaking up the larger firms. Id. at 944-48.

The Chicago School, on the other hand, "does not deny that concentration is a factor that facilitates collusion of a sort difficult to detect, although it attaches less significance to concentration per se than do the oligopoly theorists." Id. at 944-45. Above-average profit levels will either encourage new entry into the market, or if no entry is forthcoming, imply that the market "simply does not have room for many firms" due to economies of scale in production or consistent innovation by incumbents that new entrants cannot duplicate. Id. at 945. In either case, "public intervention designed to change the market structure" is not warranted. Id. "[A]n orthodox Chicago position . . . had crystallized: only explicit price fixing and very large horizontal mergers (mergers to monopoly) were worthy of serious concern." Id. at 933.

${ }^{\text {B2 }} \mathrm{R}$. PosNer, supra note 2, at 71-72.

es Id. at 72.

os Id.

${ }^{6 s} I d$. 
Although Posner and Turner address conscious parallelism from different theoretical perspectives, they share the view that section 1 enforcement should be concerned more with the effects of parallel conduct in the market than with proving the traditional elements of agreement. Both believe that it is important to examine markets in which parallel conduct occurs for indications of anticompetitive conduct, and each advocates the examination of parallel conduct under tests that are akin to the rule of reason. ${ }^{66}$ Their analyses indicate that there are two principal questions raised by the phenomenon of conscious parallelism: When may a practice be said to reflect an agreement? And if it reflects an agreement, when should it be characterized as an agreement in restraint of trade?

\section{Judicial Treatment of Conscious Parallelism Under the Sherman Act}

Section 1 of the Sherman Act refers both to prohibited means and to a prohibited end. ${ }^{67}$ The means- "contract, combination or conspiracy"-has been interpreted to require only some form of "concerted action," rather than one of the three specified arrangements. ${ }^{68}$ Moreover, the agreement need not be formal-it may be either "tacit or express." trade"-refers both to practices that, under rule-of-reason analy-

6 This characterization has been made by the Federal Trade Commission, see infra note 151 and accompanying text, and acknowledged by Posner himself when he noted the "family resemblance" between his proposal and an earlier "rule of reason" standard proposed in Conant, Consciously Parallel Action in Restraint of Trade, 38 MiNN. L. REv. 797 (1954). See Posner, supra note 49, at 1562 n.1.

77 "Section 1 specifies means as well as ends. Perhaps as a matter of public policy restraint of trade per se should be controlled but conspiracy is required in this case." Delaware Valley Marine Supply Co. v. American Tobacco Co., 297 F.2d 199, 207-08 (3d Cir. 1961) (footnote omitted), cert. denied, 369 U.S. 839 (1962).

ss As the Third Circuit has observed:

[T] he cases have interpreted the statute as "presenting a single concept about common action, not three separate ones: 'contract . . . combination or conspiracy' becomes an alliterative compound noun, roughly translated to mean 'concerted action.' There is little need to grapple with issues about the meanings of the particular words of the statute nor to mark nice distinctions among them."

Bogosian v. Gulf Oil Corp., 561 F.2d 434, 445-46 (3d Cir. 1977) (quoting L. Sullivan, supra note 35, at 312), cert. denied, 434 U.S. 1086 (1978); see also Wirtz, Purpose and Effect in Sherman Act Conspiracies, 57 WASH. L. REv. 1, 42 (1981) ("Perhaps the one generalization the Supreme Court's decisions on this issue will support is that to make out a section 1 violation there must be proof of the kind of mutual assent suggested by the word 'agreement." ").

80 See Theatre Enters., Inc. v. Paramount Film Distrib. Corp., 346 U.S. 537, 540 (1954); United States v. Paramount Pictures, Inc., 334 U.S. 131, 142 (1948). 
sis, are found to be anticompetitive in effect, ${ }^{70}$ and to a limited class of conduct that is treated as per se illegal because it is "conclusively presumed to be unreasonable."71 In determining whether to apply per se illegality, as well as in applying rule-of-reason analysis, "the inquiry is confined to a consideration of impact on competitive conditions." ${ }^{2}$ In contrast to the rule of reason, there is no defense to per se illegality once an agreement is demonstrated. ${ }^{73}$ Price-fixing agreements, whether to raise, depress, fix, or stabilize a commodity's price, are per se illegal regardless of their anticompetitive effects. ${ }^{74}$

Conscious parallelism first emerged as a theory of antitrust liability in actions brought under section 5 of the Federal Trade

${ }^{70}$ See, e.g., National Soc'y of Professional Eng'rs v. United States, 435 U.S. 679, 690 (1978). Professor, now Judge, Frank Easterbrook has criticized this formulation of the rule of reason as "empty." Easterbrook, The Limits of Antitrust, 63 TEx. L. REv. 1, 12 (1984). He argues that the definition of the rule of reason currently employed by the courts is too vague to offer useful guidance to judges. Id. He suggests as an alternative the use by courts of a series of presumptions, based on economic theory, to aid in deciding whether conduct is "anticompetitive." Id. at 14-39.

${ }^{71}$ Northern Pac. Ry. v. United States, 356 U.S. 1, 5 (1958). Several categories of conduct have been labeled per se illegal, including (1) price-fixing, both vertical and horizontal; (2) tying arrangements where a seller permits a buyer to purchase a desired item (the tying product) over which the seller has market power only if the buyer also agrees to purchase a second item (the tied product) from the seller; (3) group boycotts or concerted refusals to deal; and (4) horizontal market divisions. See 2 Julian von Kalinowski, ANTITrust Laws \& Trade Regulation $\$ 6.02[1]$ (1984). Nonetheless, the application of the per se rule to vertical price-fixing and tying arrangements has come under attack recently. See, e.g., RoBERT Bork, The ANTitrust Paradox 372-74 (1978) (tying arrangements); Baker, Interconnected Problems of Doctrine and Economics in the Section One Labyrinth: Is Sylvania a Way Out?, 67 VA. L. REv. 1457, 1465-66 (1981) (vertical price restrictions). In Monsanto Co. v. Spray-Rite Serv. Corp., 104 S. Ct. 1464, 1469 n.7 (1984), the Court took note of the arguments against application of the per se rule to vertical price fixing. Indeed, the Solicitor General of the United States submitted an amicus brief urging the Court to reconsider the rule. See Brief for the United States as Amicus Curiae in Support of Petitioner at 19-29, Monsanto. The Court refused this invitation, however, see $104 \mathrm{~S}$. Ct. at $1469 \mathrm{n.7}$, and decided the case on the evidentiary issues presented by the parties.

In Jefferson Parish Hosp. Dist. No. 2 v. Hyde, 104 S. Ct. 1551, 1560-61 (1984), a bare majority of the Court affirmed the application of the per se rule to tying arrangements in cases in which the seller has market power over the tying product. But Justice O'Connor, joined by three other members of the Court, argued that the per se rule should be scrapped. Id. at 1570-74 (O'Connor, J., concurring).

72 See National Soc'y of Professional Eng'rs v. United States, 435 U.S. 679, 690 (1978). As one lower court explained: "The ultimate test of legality, of course, is whether the particular restraint promotes or impairs competition. But . . the intent or purpose underlying the restraint is a crucial variable in aiding the court to assess the competitive effects of the restraint." Martin B. Glauser Dodge Co. v. Chrysler Corp., 570 F.2d 72, 82-83 (3d Cir. 1977), cert. denied, 436 U.S. 913 (1978).

${ }^{73}$ See R. Bork, supra note 71, at 66.

74 United States v. Socony-Vacuum Oil Co., 310 U.S. 150, 223-24 (1940). 
Commission Act (FTCA). ${ }^{75}$ The textual basis for this theory is much stronger under the FTCA than under section 1 of the Sherman Act because section 5 does not include a concerted-action requirement. ${ }^{76}$ Commentators have suggested, however, that even in early Sherman Act cases recognizing the doctrine, courts seemed to equate conscious parallelism with agreement. ${ }^{77}$ These decisions permitted the inference of a price-fixing conspiracy without direct evidence that a formal agreement to adopt parallel marketing practices had been reached. ${ }^{78}$ In Theatre Enterprises, Inc. v. Paramount Film Distributing Corp., ${ }^{79}$ however, the Supreme Court held that conscious parallelism was not equivalent to agreement for the purposes of section 1 :

[B] usiness behavior is admissible circumstantial evidence from which the fact finder may infer agreement. . . . But this Court has never held that proof of parallel business behavior

${ }^{75} 15$ U.S.C. $\$ 45(a)(1)$ (1982) ("Unfair methods of competition in or affecting commerce, and unfair or deceptive acts or practices in or affecting commerce, are declared unlawful."). See, e.g., Triangle Conduit \& Cable Co. v. FTC, 168 F.2d 175, 176 (7th Cir. 1948), aff'd sub nom. Clayton Mark \& Co. v. FTC, 336 U.S. 956 (1949). In Triangle Conduit, the second count of the FTC's complaint, unlike the first count, did not allege an agreement, but alleged a violation of section 5 " 'through [the defendants'] concurrent use of a formula method of making delivered price quotations with the knowledge that each did likewise, with the result that price competition between and among them was unreasonably restrained." "168 F.2d at 176. The Seventh Circuit upheld the FTC's finding that these parallel practices, even absent an agreement among the parties, were an unfair method of competition under section 5 of the FTCA. Id. at 181. For a discussion of Triangle Conduit and its implications for section 5 of the FTCA, see Note, Conscious Parallelism in the Use of Delivered Pricing Systems: A Modified Per Se Standard of Review Under the Federal Trade Commission Act, 66 Cornell L. Rev. 1194 (1981).

${ }^{76}$ See Note, supra note 75, at 1203-11.

72 See Blechman, Conscious Parallelism, Signalling and Facilitating Devices: The Problem of Tacit Collusion Under the Antitrust Laws, 24 N.Y.L. ScH. L. REv. 881, 882-85 (1979); Rostow, The New Sherman Act: A Positive Instrument of Progress, 14 U. CHI. L. REv. 567, 584 (1947) ("Parallel action based on acknowledged self-interest within a defined market structure is sufficient evidence of illegal action.").

78 For example, in Interstate Circuit, Inc. v. United States, 306 U.S. 208 (1939), the alleged conspiracy was between two Texas motion picture exhibitors and eight national film distributors. Although the distributors met individually with the exhibitors, and each was aware that the other seven had received identical letters from the film exhibitors proposing the marketing changes that were eventually adopted, no evidence was offered that all eight distributors ever met to discuss the new marketing procedures. In affirming the illegality of the arrangement, the Supreme Court reasoned:

It is elementary that an unlawful conspiracy may be and often is formed without simultaneous action or agreement on the part of the conspirators. . . Acceptance by competitors, without previous agreement, of an invitation to participate in a plan, the necessary consequence of which, if carried out, is restraint of interstate commerce, is sufficient to establish an unlawful conspiracy under the Sherman Act.

Id. at 227 (citations omitted).

79346 U.S. 537 (1954). 
conclusively establishes agreement or . . . that such behavior itself constitutes a Sherman Act offense. Circumstantial evidence of consciously parallel behavior may have made heavy inroads into the traditional judicial attitude toward conspiracy; but "conscious parallelism" has not yet read conspiracy out of the Sherman Act entirely. ${ }^{80}$

After Theatre Enterprises, lower courts have held that parallel conduct is sufficient evidence of agreement only when additional evidence, or "plus factors," is presented. ${ }^{81}$ The most consistently used plus factor is proof that the parallel practices were contrary to each firm's apparent self-interest, ${ }^{82}$ a fact that is usually established by examining whether there were any legitimate business justifications for the conduct. Other plus factors include high-level interfirm communication, ${ }^{83}$ artificial standardization of products, ${ }^{84}$ and price increases during times of low demand. ${ }^{85}$

Under the "business justifications" test, courts have addressed the propriety of a broad range of conduct that falls between the

${ }^{80}$ Id. at $540-41$ (citations and footnote omitted).

81 See, e.g., Weit v. Continental Ill. Nat'l Bank \& Trust Co., 641 F.2d 457, 462-63 (7th Cir. 1981), cert. denied, 455 U.S. 988 (1982); Delaware Valley Marine Supply Co. v. American Tobacco Co., 297 F.2d 199, 202-03 (3d Cir. 1961), cert. denied, 369 U.S. 839 (1962). The term "plus factor" actually was employed before the Theatre Enterprises decision. See CO-Two Fire Equip. Co. v. United States, 197 F.2d 489, 497 (9th Cir.), cert. denied, 344 U.S. 892 (1952).

${ }_{82}$ See, e.g., Milgram v. Loew's, Inc., 192 F.2d 579, 583 (3d Cir. 1951) (conduct in "apparent contradiction to [each defendant's] own self-interest . . . strengthens considerably the inference of conspiracy") (emphasis added), cert. denied, 343 U.S. 929 (1952). Taking plus-factor analysis one step further, the Ninth Circuit reasoned that the inference of conspiracy from parallel business behavior "might have been permissible in the absence of evidence showing that their respective actions were prompted by some fact other than mutual understanding or agreement." Independent Iron Works, Inc. v. United States Steel Corp., 322 F.2d 656, 661 (9th Cir.) (emphasis added), cert. denied, 375 U.S. 922 (1963). Numerous decisions have held that the inference of conspiracy from parallel conduct is permissible "where the pattern of action undertaken is inconsistent with the self-interest of the individual actors, were they acting alone." Admiral Theatre Corp. v. Douglas Theatre Co., 585 F.2d 877, 884 (8th Cir. 1978); accord Proctor v. State Farm Mut. Auto. Ins. Co., 675 F.2d 308, 327 (D.C. Cir.), cert. denied, 459 U.S. 839 (1982); Pan-Islamic Trade Corp. v. Exxon Corp., 632 F.2d 539, 559 (5th Cir. 1980), cert. denied, 454 U.S. 927 (1981); Modern Home Inst., Inc. v. Hartford Accident \& Indem. Co., 513 F.2d 102, 111 (2d Cir. 1975).

${ }^{83}$ See, e.g., In re Plywood Antitrust Litig., 655 F.2d 627, 633-34 (5th Cir. 1981), cert. dismissed sub nom. Lyman Lamb v. Weyerhauser, 462 U.S. 1125 (1983); Gainesville Util. Dep't v. Florida Power \& Light Co., 573 F.2d 292, 301 (5th Cir.), cert. denied, 439 U.S. 966 (1978).

s4 See C-O-Two Fire Equip. Co. v. United States, 197 F.2d 489, 497 (9th Cir.), cert. denied, 344 U.S. 892 (1952).

${ }^{85}$ See American Tobacco Co. v. United States, 328 U.S. 781, 805 (1946); C-O-Two Fire Equip. Co. v. United States, 197 F.2d 489, 497 (9th Cir.), cert. denied, 344 U.S. 892 (1952). For a list of additional plus factors, see Blechman, supra note 77, at 885-87. 
two extremes (formal cartel and monopolistic competition) that may constitute concerted action. In accord with the view of the Harvard School that firms recognize and act upon their mutual interdependence, courts have held that "[s]imilarity of prices in the sale of standardized products . . . will not alone make out a prima facie case of collusive price-fixing," ${ }^{86}$ and that price leadership, ${ }^{87}$ standing alone, does not constitute an agreement in restraint of trade. ${ }^{88}$ Industry-wide adoption of such mechanisms as delivered ${ }^{89}$ and two-tiered pricing, ${ }^{90}$ however, has been deemed sufficient to support the inference of agreement. ${ }^{91}$

Courts have differed over the meaning of "conduct against self-interest" under the business-justifications test. The general standard, which requires " a showing of acts by defendants in con-

st FTC v. Lukens Steel Co., 454 F. Supp. 1182, 1190 n.9 (D.D.C. 1978); accord Weit v. Continental Ill. Nat'l Bank \& Trust Co., 641 F.2d 457, 463 (7th Cir. 1981), cert. denied, 455 U.S. 988 (1982); Independent Iron Works, Inc. v. United States Steel Corp., 322 F.2d 656, 665 (9th Cir.), cert. denied, 375 U.S. 922 (1963). The Lukens court noted that "price identity may be the expected and normal result when the product is identical or fungible, even though there is no agreement and the costs for the participating companies are not the same." $454 \mathrm{~F}$. Supp. at 1190.

${ }^{37}$ Price leadership is an industry practice in which one firm's pricing movements are followed by its rivals. See P. Asch, supra note 28, at 66-69.

ss "An accidental or incidental price uniformity, or even 'pure' conscious parallelism of prices is, standing alone, not unlawful. Nor is an individual competitor's sole decision to follow a price leadership, standing alone, a violation of law." Esco Corp. v. United States, 340 F.2d 1000, 1007 (9th Cir. 1965); see also United States v. International Harvester Co., 274 U.S. 693, 708-09 (1927) ("[T] he fact that competitors may see proper, in the exercise of their own judgment, to follow the prices of another manufacturer, does not establish any suppression of competition or show any sinister domination.") (citations omitted).

so In re Plywood Antitrust Litig., 655 F.2d 627, 631-32, 634 (5th Cir. 1981), cert. dismissed sub nom. Lyman Lamb v. Weyerhauser, 462 U.S. 1125 (1983).

?o Ambook Enters. v. Time Inc., 612 F.2d 604, 611-18 (2d Cir. 1979), cert. dismissed, 448 U.S. 914 (1980).

"I In establishing the existence of conscious parallelism, a showing of exact uniformity of action is not required. Nevertheless, "more than a general similarity of action" must be shown. Harlem River Consumers Coop., Inc. v. Associated Grocers, 408 F. Supp. 1251, 1277 (S.D.N.Y. 1976); see also Delaware Valley Marine Supply Co. v. American Tobacco Co., 297 F.2d 199, 204 (3d Cir. 1961) (requiring only "uniformity of action on a crucial point"), cert. denied, 369 U.S. 839 (1962).

Courts have not articulated the reason for this distinction, although the Ninth Circuit has indicated that " 'pure' conscious parallelism of prices is, standing alone, not unlawful." Esco Corp. v. United States, 340 F.2d 1000, 1007 (9th Cir. 1965). This suggests a difference in treatment consistent with the theory of monopolistic competition. Chamberlin theorized that once monopolistic competitors recognized their interdependence, they would, without communication, set prices at the monopoly level. See supra notes 30-31 and accompanying text. Conduct beyond such "pure parallelism," such as the adoption of practices that facilitate coordination to reach the monopoly price, would be unnecessary and cannot be explained as the expected result of monopolistic competition. 
tradiction of their own economic interests," "92 is particularly unhelpful. Economists assume that a firm always acts in its own perceived self-interest, ${ }^{93}$ and there is no apparent reason why a court should reject this assumption. Moreover, it is in a firm's interest to maximize profits by entering into a cartel arrangement. A firm could therefore argue unabashedly that any practice that increases prices, including a cartel, would also further the firm's own interests by increasing its profits.

A more useful rule, which has been adopted by several courts, avoids these difficulties by allowing the inference of agreement "[o]nly where the pattern of action undertaken is inconsistent with the self-interest of the individual actors, were they acting alone." This test meshes well with cartel theory, which suggests that group action contrary to each firm's independent profit-maximizing conduct is needed in order to attain a monopoly price. ${ }^{95}$

${ }^{82}$ Bogosian v. Gulf Oil Corp., 561 F.2d 434, 446 (3d Cir. 1977) (quoting Venzie Corp. v. United States Mineral Prods. Co., 521 F.2d 1309, 1314 (3d. Cir. 1975)), cert. denied, 434 U.S. 1086 (1978).

${ }^{83}$ See E. Mansfield, supra note 15, at 141-43.

84 Admiral Theatre Corp. v. Douglas Theatre Co., 585 F.2d 877, 884 (8th Cir. 1978); see also Proctor v. State Farm Mut. Auto Ins. Co., 675 F.2d 308, 327 (D.C. Cir.) (agreement may be inferred "[o]nly when the observed parallel behavior is inconsistent with the behavior to be expected from each actor individually pursuing its own economic interest"), cert. denied, 459 U.S. 839 (1982); Modern Home Inst., Inc. v. Hartford Accident \& Indem. Co., 513 F.2d 102, 111 (2d Cir. 1975) (basis for inference of conspiracy may be actions that are in one's self-interest only if done in concert with others).

${ }^{85}$ See supra notes 17-19 and accompanying text. The business justifications proffered by firms have been as varied as the products they sell. In Weit v. Continental Ill. Nat'l Bank \& Trust Co., 641 F.2d 457 (7th Cir. 1981), cert. denied, 455 U.S. 988 (1982), three justifications were offered by the defendant commercial banks in response to the plaintiffs' claim that the industry-wide $1.5 \%$ per month interest fee on an inter-bank charge card system was the product of a price-fixing conspiracy: each of the banks had parallel costs for operating their charge card systems; each had "identical problems of fraud, credit losses, and large initial expense, to which reasonable businessmen would react in the same fashion"; and, $1.5 \%$ was the rate then charged on other consumer credit cards. 641 F.2d at 461 . The Seventh Circuit found that these explanations were sufficient to preclude the inference of unlawful conspiracy, despite evidence that the banks had adopted the inter-bank system at the same time and had met frequently to discuss its operation. Id. at 463.

In Proctor v. State Farm Mut. Auto. Ins. Co., 675 F.2d 308 (D.C. Cir.), cert. denied, 459 U.S. 839 (1982), several automobile repair shops alleged that five insurance companies had conspired to fix the price of automobile damage repair work. The repair shops offered evidence of parallel conduct that included the use of the same labor rate in writing estimates, similar arrangements with repair shops that agreed to do volume work at lower rates, use of surveys of repair shops to determine the average rate charged by shops in particular areas, and a tendency to resist price increases by repair shops. $675 \mathrm{~F} .2 \mathrm{~d}$ at 311,330 . The court found that these practices did not support an inference of conspiracy because they served the economic self-interest of each insurance company by reducing the costs oi automobile repair. Id. at 330 . The court observed that surveys are a means of locating low-price repair shops. Id. Similarly, the use of repair shops willing to charge rates set by insurance compa- 
The most elaborate formulation of the test, however, was provided by the Third Circuit in Venzie Corp. v. United States Mineral Products $\mathrm{Co.}_{.,{ }^{96}}$ where the court synthesized from prior decisions a two-pronged test for permitting the inference of agreement from conscious parallelism: there must be (1) a showing of acts by defendants in contradiction of their own economic interests and (2) a satisfactory demonstration of motivation to enter into an agreement. ${ }^{97}$ The "Venzie test" is based upon the observation that business behavior does not permit the inference of agreement "unless the circumstances under which it occurred make the inference of rational, independent choice less attractive than that of concerted action."

The Venzie test differs from standards developed by other courts because it requires proof that there was a motive to conspire. ${ }^{99}$ The motive for entering into a price-fixing arrangement is usually straightforward-the higher cartel price allows a firm to capture a share of the monopoly profits. The motive element of the Venzie test, however, is not designed to show why a cartel might have been formed. Rather, it is used to demonstrate that an individual firm was in a position to benefit from specified concerted action. ${ }^{100}$ As the Supreme Court has suggested, the motive analysis may provide an escape by way of a summary judgment for defendants who have adopted industry-wide parallel business practices, but who nonetheless have nothing to gain from the alleged agreement. $^{101}$

nies in exchange for volume referrals is also in the self-interest of each insurance company since it reduces costs. Id. at 331-33.

5621 F.2d 1309 (3d Cir. 1975).

27 Id. at 1314; see also Schoenkopf v. Brown \& Williamson Tobacco Corp., 637 F.2d 205 (3d Cir. 1980) (using the same approach); Bogosian v. Gulf Oil Corp., 561 F.2d 434, 446 (3d Cir. 1977) (same), cert. denied, 434 U.S. 1086 (1978).

9s Bogosian v. Gulf Oil Corp., 561 F.2d 434, 446 (3d Cir. 1977), cert. denied, 434 U.S. 1086 (1978).

28 See, e.g., Pan-Islamic Trade Corp. v. Exxon Corp., 632 F.2d 539, 559 (5th Cir. 1980), cert. denied, 454 U.S. 927 (1981); Admiral Theatre Corp. v. Douglas Theatre Co., 585 F.2d 877, 884 (8th Cir. 1978).

${ }^{100}$ See First Nat'l Bank v. Cities Serv. Co., 391 U.S. 253, 287 (1968), where, in discussing its prior decision in Interstate Circuit, Inc. v. United States, 306 U.S. 208 (1939), the Court wrote: "The reason that the absence of direct evidence of agreement . . . was not fatal is that the distributors all had the same motive to enter into a tacit agreement." Presumably that motive was greater profits from monopoly prices.

${ }^{10}$ See First Nat'l Bank v. Cities Serv. Co., 391 U.S. 253, 287 (1968). In fact, the Supreme Court in Cities Service upheld a dismissal from an action alleging a concerted refusal to deal on a motion for summary judgment for lack of motive. Id. at 287-88. For a discussion of the appropriate test for weighing competing inferences drawn from the independent selfinterest test for a summary judgment motion, see Note, Conscious Parallelism: The Busi- 
An example of this use of the motive inquiry is Japanese Electronic Products Antitrust Litigation, ${ }^{102}$ where one of the defendants, Sony, was granted summary judgment on charges of engaging in a price-fixing conspiracy with other Japanese television manufacturers, on the ground that no motive to conspire had been shown. ${ }^{103}$ The plaintiffs, American television manufacturers, had asserted that the Japanese defendants had conspired to raise prices in their domestic market and to dump televisions in the United States at below-cost prices. ${ }^{104}$ Although Sony had engaged in the practice of selling television sets in the United States at prices significantly below the prices charged in Japan for comparable sets, the Third Circuit found that, unlike the other defendants, Sony did not compete in the low-price segment of the market where the plaintiffs sold their televisions. ${ }^{105}$ The court thus held that "[a]bsent some evidence suggesting . . . a motive [to join the conspiracy] the remaining evidence is entirely too speculative to support a prima facie case against Sony."106

One problem that arises under the second prong of the Venzie test is identifying what motives would be sufficient to defeat a defendant's motion for summary judgment. For example, the required motive could be a desire to earn monopoly profits, or it might only be some less objectionable interest, such as a desire to cultivate good business relations with the cartel. Perhaps any po-

ness Judgment Defense in a Summary Judgment Context, 35 Hastings L.J. 115 (1983). The Seventh Circuit has found the similarities between the per se test employed under section 1 conspiracy-to-fix-prices and group-boycott cases sufficient to warrant application of the Cities Service standard in the former. Weit v. Continental Ill. Nat'l Bank \& Trust Co., 641 F.2d 457, 465 (7th Cir. 1981), cert. denied, 455 U.S. 988 (1982).

${ }_{102} 723$ F.2d 238 (3d Cir. 1983), cert. granted sub nom. Matsushita Elec. Indus. Co. v.

Zenith Radio Corp., 105 S. Ct. 1863 (1985).

103723 F.2d at 313.

104 Id. at 305-06. Among the practices alleged were agreements that each manufacturer would confine itself to sales to five companies in the United States (i.e., market division), secret rebates to retailers, and sales at prices that produced losses. The Third Circuit held that a trier of fact could infer that the Japanese had a strong motive to sell their product at low prices because they had higher fixed costs, providing an incentive to use manufacturing capacity at the highest possible levels. The fact that Japanese manufacturers are expected to maintain the "permanence and stability of their workforce" was cited as one source of the higher fixed costs. Id. at 307.

205 Id. at 313.

${ }^{108}$ Id. Another defendant, Sears Roebuck, was also dismissed on summary judgment despite evidence that it had solicited and then concealed from the Japanese and United States governments dumping prices (in apparent contradiction to its own interest as a onefourth owner of an American television manufacturer). Id. at 312-13. Because the solicitation of low prices was consistent with Sears' economic interest as a retailer, the court held "that circumstance is so slightly probative of a motive to join a conspiracy as, on this record, to be valueless." Id. at 312 . 
tential benefit to the defendant, no matter how slight, should be enough. But if the motive requirement is read too broadly, the benefits of judicial economy accruing from the test would disappear; a broad reading would also increase the risk that firms who have not in fact colluded will be held liable for price fixing. Thus, plaintiffs must be required to suggest a plausible motive to collude on the part of each defendant that is of "such importance that [they] would risk possible antitrust liability."10z

The Venzie formulation of the business-justifications test is an appropriate starting point for analyzing parallel practices because it screens out mere parallel pricing, behavior that is consistent with "natural" monopolistic competition, and because it requires, as a first approximation, some indication of interdependence among firms that may rise to the level of concerted action. In this sense, it meets the concerns of the Harvard School, which suggests that behavior that is consistent with monopolistic competition in its pure form should not, by itself, be a basis for finding agreement. $^{108}$

The Venzie test alone, however, may be inadequate for conclusively determining liability under section 1 . The test is aimed solely at finding agreement, not at identifying parallel conduct that is anticompetitive; section 1 , however, requires not only agreement, but also a restraint of trade-that is, an anticompetitive effect-as a consequence of the agreement. Furthermore, the theories of both the Chicago and Harvard Schools suggest that the validity of coordinated conduct going beyond "pure" pricing practices does not depend on whether independent business justifications exist; it must also be shown that the market does not behave as it would be expected to behave under "normal" competitive conditions. ${ }^{109}$ Only if tacit collusion is found to go beyond the making of interdependent pricing decisions, so that the practice actually facilitates price fixing, should it fall within the proscription of section 1 .

By ending the inquiry after agreement has been found, the Venzie test, and similar tests currently used by most courts, implicitly incorporates the conclusion that all agreements to engage in parallel pricing practices are anticompetitive: such agreements are treated as anticompetitive, and hence illegal, per se. ${ }^{110}$ The re-

${ }^{107}$ FTC v. Lukens Steel Co., 454 F. Supp. 1182, 1197 n.18 (D.D.C. 1978).

${ }_{108}$ See supra notes 30-33 and accompanying text.

${ }^{109}$ See supra notes 44-48, 62-65 and accompanying text.

110 See cases cited supra note 9 . It might be argued that the motive prong of the Venzie test precludes the need for a rule-of-reason analysis. But while evidence of the purpose be- 
mainder of this comment will examine the propriety of the per se rule and will show that such an approach should be rejected in favor of a rule-of-reason analysis as a supplement to the businessjustifications test.

\section{Identifying Restraints of Trade: Independent Business JUSTIFICATIONS AND THE RULE OF REASON}

\section{A. Per Se Rule Versus Rule-of-Reason Analysis}

At first blush, it may appear that per se illegality, rather than rule-of-reason analysis, ${ }^{111}$ should govern cases in which a tacit agreement is proved; this would accord with precedent suggesting that naked price-fixing agreements, even those among small firms without market power, are illegal. ${ }^{112}$ As the Supreme Court re-

hind a practice may buttress a finding that the practice impairs competition, it is not by itself sufficient to support this conclusion. See supra note 72 and accompanying text. As the Supreme Court has stressed, "the purpose of the [rule-of-reason] analysis is to form a judgment about the competitive significance of the restraint." National Soc'y of Professional Eng'rs v. United States, 435 U.S. 679, 692 (1978) (emphasis added). Moreover, the motive requirement of the Venzie test is intended as a procedural device to screen out those parties that could have no relevant reason for entering a conspiracy of the type alleged. A showing of a possible motive does no more than to keep a party in the case. It does not prove that the party had the anticompetitive purpose that is an element of the substantive offense. $C f$. W. LaFave \& A. ScotT, Handbook on Criminal LAW $\$ 29$ (1972) (arguing that in the criminal law, intent, but not motive, is relevant in substantive issues while motive is relevant in procedural matters, such as the exercise of prosecutorial discretion not to invoke the criminal process).

11 As the Supreme Court explained:

The [rule of reason] test prescribed in [Standard Oil Co. v. United States, 221 U.S. 1, 58 (1911),] is whether the challenged contracts or acts "were unreasonably restrictive of competitive conditions." Unreasonableness under that test could be based either (1) on the nature or character of the contracts, or (2) on surrounding circumstances giving rise to the inference or presumption that they were intended to restrain trade and enhance prices. Under either branch of the test, the inquiry is confined to a consideration of impact on competitive conditions.

National Soc'y of Professional Eng'rs v. United States, 435 U.S. 679, 690 (1978) (footnote omitted). See also Board of Trade v. United States, 246 U.S. 231, 238 (1918), where the Court noted that it must

consider the facts peculiar to the business to which the restraint is applied; its condition before and after the restraint was imposed; the nature of the restraint and its effect, actual or probable. The history of the restraint, the evil believed to exist, the reason for adopting the particular remedy, the purpose or end sought to be attained, are all relevant facts.

For discussion of a proposal to discard per se analysis for all price-fixing cases, see Note, Fixing the Price Fixing Confusion: A Rule of Reason Approach, 92 YALE L.J. 706 (1983).

112 See, e.g., Broadcast Music, Inc. v. Columbia Broadcasting Sys., 441 U.S. 1, 8 (1979); United States v. Socony-Vacuum Oil Co., 310 U.S. 150, 223-24 (1940); United States v. Realty Multi-List, Inc., 629 F.2d 1351, 1365 (5th Cir. 1980). 
cently emphasized in Broadcast Music, Inc. v. Columbia Broadcasting System, ${ }^{113}$ however, not all agreements to fix prices are subject to the per se rule. ${ }^{114}$

As a preliminary matter, a court must determine whether the challenged conduct properly falls within the ambit of the per se rule. ${ }^{115}$ The inquiry, however, must transcend the facts of any particular case. The court must look to the class of conduct generally, not as it manifests itself in a particular market. As the Court noted in Broadcast Music, "[t] he scrutiny . . . must not merely subsume the burdensome analysis required under the rule of reason . . . or else we should apply the rule of reason from the start." 116

In making this generalized inquiry, the court must first balance "[ $t]$ he probability that anticompetitive consequences will result from a practice and the severity of those consequences . . . against its procompetitive consequences." 117 Application of the per se rule reflects a judgment that the instances in which the challenged form of conduct is actually procompetitive are so rare or unimportant that it is not worth expending judicial resources to determine whether a particular instance of the practice is indeed procompetitive. ${ }^{118}$ But, as the Court stated in Broadcast Music, it is only "after considerable experience with the type of challenged restraint" that courts classify them as per se violations. ${ }^{119}$ Thus, if the courts are uncertain about the competitive effect of a practice,

113441 U.S. 1 (1979).

11 As generally used in the antitrust field, "price-fixing" is a shorthand way of describing certain categories of business behavior to which the per se rule has been held applicable. . . . Literalness is overly simplistic and often overbroad. When two partners set the price of their goods or services they are literally "price fixing," but they are not per $s e$ in violation of the Sherman Act.

Id. at 9.

s1 [T] ] existence of a per se rule should not, and logically cannot, preclude a court from determining whether the per se rule should be applied. The applicability of the per se rule is not an issue that is foreclosed by the existence of a per se rule. If the characteristics of a case are so different from previous per se cases that the substantive policy embodied in the per se rule is no longer applicable, the rule should not be applied.

Gerhart, The Supreme Court and Antitrust Analysis: The (Near) Triumph of the Chicago School, 1982 Sup. CT. REv. 319, 327.

11641 U.S. at 19 n.33 (citation omitted); cf. Board of Regents v. NCAA, 707 F.2d 1147, 1155 (10th Cir. 1983) ("II]n assessing the facial validity of an integration, courts are not to engage in rule of reason analysis."), aff'd, $104 \mathrm{~S}$. Ct. 2948 (1984).

${ }_{11}$ Continental T.V., Inc. v. GTE Sylvania Inc., 433 U.S. 36, 50 n.16 (1977).

11 See id.

11941 U.S. at 19 n.33; see also United States v. Topco Assocs., 405 U.S. 596, 607-08 (1972); Northrop Corp. v. McDonnell Douglas Corp., 705 F.2d 1030, 1051 (9th Cir.), cert. denied, 104 S. Ct. 156 (1983). 
the per se rule is not applied. ${ }^{120}$

Another precondition for applying the per se rule is that it give clear "guidance to the business community" and reduce "the burdens on litigants and the judicial system of more complex ruleof-reason trials." ${ }^{21}$ These advantages do not accompany every application of the per se rule, however, and even when they do, they have been held to be insufficient, by themselves, to justify the per se approach. ${ }^{122}$

Furthermore, the Court stated in Broadcast Music that a practice should be condemned as per se illegal only when it is clear, without engaging in an elaborate inquiry, that the practice is "one that would always or almost always tend to restrict competition and decrease output." ${ }^{123}$ In Broadcast Music itself, the Court refused to apply the per se rule to a price-fixing agreement in which it was uncertain whether the intent or effect of the agreement was to restrain competition. ${ }^{124}$

Under this generalized inquiry, tacit agreement inferred from

${ }^{120}$ See United States v. Realty Multi-List, Inc., 629 F.2d 1351, 1365 (5th Cir. 1980); see also Northrop Corp. v. McDonnell Douglas Corp., 705 F.2d 1030, 1053 (9th Cir.) (where effect on competition "is equivocal, it is appropriate to examine the purpose of the restraint in deciding whether to apply the per se rule"), cert. denied, 104 S. Ct. 156 (1983); United States v. Studiengesellschaft Kohle, m.b.H., 670 F.2d 1122, 1130 (D.C. Cir. 1981) ("[PJer se rules risk sweeping reasonable, procompetitive activity within a general condemnation, and a court will run this risk only where dictated on the basis of unambiguous experience.").

${ }^{121}$ Continental T.V., Inc. v. GTE Sylvania Inc., 433 U.S. 36, 50 n.16 (1977).

122 United States v. Realty Multi-List, Inc., 629 F.2d 1351, 1365 (5th Cir. 1980). The per se rule often reduces litigation costs because it proscribes conduct without regard to actual effect, thus saving the often monumental expense of investigating the economic structure of an entire industry. See Northern Pac. Ry. v. United States, 356 U.S. 1, 5 (1958) (per se rule avoids "the necessity for an incredibly complicated and prolonged economic investigation into the entire history of the industry involved, as well as related industries").

${ }^{123} 441$ U.S. at $19-20$.

124 Broadcast Music involved an arrangement between music composers and two firms, ASCAP and BMI, that allowed the firms to negotiate with music consumers for a blanket license for performing rights to all of the composers' copyrighted works. BMI and ASCAP refused to grant performance rights for individual scores, but the music consumer had the option of negotiating with each composer. 441 U.S. at 6 . While the agreement literally involved price fixing-the composers and publishing houses had joined together into an organization that set its price for the blanket license--the Court held that it was not per se illegal. Id. at 9, 20. The Court found that the challenged arrangement might be procompetitive because it facilitated the integration of sales and the monitoring of, and enforcement against, unauthorized use of the composers' works. $I d$. at 13,21 . The blanket license, the Court found, "is a necessary consequence of the integration necessary to achieve these efficiencies, and a necessary consequence is that its price must be established." Id. at 21 . While demonstrated efficiency alone "might not remove a naked price-fixing scheme from the ambit of the per se rule ... here we are uncertain whether the practice on its face has the effect, or could have been spurred by the purpose, of restraining competition among the individual composers." Id. at 13. 
parallel behavior under the business-justifications test should not be considered per se illegal, for several reasons. First, economic theory suggests that informal agreement cannot be successful except in the context of oligopoly. ${ }^{125}$ As the number of participating firms increases, it becomes impossible to detect violations and enforce the agreement. The resulting incentive for each member to undercut the agreed-upon monopoly price, without fear of sanction, soon leads to complete erosion of the monopoly price. ${ }^{126}$ Thus, it simply cannot be said that tacit collusion would almost always tend to restrict competition.

Second, the Venzie test can lead to an inference that the parties have agreed to adopt parallel conduct that may affect price. But this inference is permitted only after an examination of the business justifications-an examination that usually entails the very kind of elaborate inquiry that the Court suggests should preclude use of the per se rule. ${ }^{127}$ Furthermore, nothing in the test itself supports the further inference that a particular parallel practice has anticompetitive effects. Thus, conclusively presuming such effects on the basis of the test violates the admonition in Broadcast Music against casually assuming that all agreements affecting price are illegal price-fixing agreements. ${ }^{128}$

Third, the market consequences of many parallel business

${ }^{123}$ See supra notes 18-19, 26-27 and accompanying text.

128 There is no consensus among economists about the level of concentration above which collusion becomes an attractive proposition. R. PoSNER, supra note 2, at 55-56. Concentration levels interact with other market factors to create suitable conditions for successful collusion. Id.

${ }^{127}$ The classic statement of the rationale behind per se illegality is found in Northern Pac. Ry. v. United States, 356 U.S. 1, 5 (1958): "[T] which because of their pernicious effect on competition and lack of any redeeming virtue are conclusively presumed to be unreasonable and therefore illegal without elaborate inquiry as to the precise harm they have caused or the business excuse for their use."

Analysis of independent business justifications under the Venzie test is an example of such an "elaborate inquiry." In Jefferson Parish Hosp. Dist. No. 2 v. Hyde, 104 S. Ct. 1551 (1984), Justice O'Connor, in a concurring opinion, argued on similar grounds that the per se rule against product-tying arrangements should be abandoned:

The "per se" doctrine in tying cases has . . . always required an elaborate inquiry into the economic effects of the tying arrangement. As a result, tying doctrine incurs the costs of a rule of reason approach without achieving its benefits: the doctrine calls for the extensive and time-consuming economic analysis characteristic of the rule of reason, but then may be interpreted to prohibit arrangements that economic analysis would show to be beneficial. Moreover, the per se label in the tying context has generated more confusion than coherent law because it appears to invite lower courts to omit the analysis of economic circumstances of the tie that has always been a necessary element of tying analysis.

Id. at 1570 (O'Connor, J., concurring) (footnote omitted).

${ }^{128}$ See supra notes $114-16$ and accompanying text. 
practices are ambiguous. For example, delivered pricing may facilitate collusion by standardizing shipping charges and making it easier to maintain a cartel price. Without delivered pricing, a firm could effectively cut price by offering lower freight charges rather than a lower product price-a practice that would disguise cheating. ${ }^{129}$ But delivered pricing may also be procompetitive. When freight costs constitute a small percentage of the price of the delivered product, it may be more efficient to charge all buyers the same price and avoid the expense of determining individual freight charges. Moreover, delivered pricing may be adopted because customers wish to avoid the risk of price fluctuations due to freight cost variations. ${ }^{130}$ Thus, it cannot be concluded that the instances in which parallel conduct is actually procompetitive are so rare or unimportant that the savings in judicial resources resulting from the application of the per se rule justify the risk of error. ${ }^{131}$

\section{B. A Two-Step Approach}

These considerations show that it is improper to apply the per se rule in cases of tacit collusion, or to rely solely on the businessjustifications test to determine the validity of such practices under section 1 . In order to show both agreement and restraint of trade, parallel practices should be examined under a two-pronged inquiry-first, the business-justifications test, and second, rule-ofreason analysis.

Under the first prong of this approach, the plaintiff must establish a prima facie case by proving conscious parallelism and suggesting a motive for the defendants to collude. The burden of coming forward with evidence that the conduct would have been in

${ }^{128}$ Carlton, A Reexamination of Delivered Pricing Systems, 26 J.L. \& EcoN. 51, 53 (1983).

190 Id. at 65.

1s! Furthermore, some courts have shown little zeal to impose liability for tacit agreement to fix prices without some proof that the parallel conduct has an adverse effect on the market. See Givens, Parallel Business Conduct Under the Sherman Act, 5 AnTitrust Buld. 273, 282-87 (1960). For example, in Ambook Enters. v. Time Inc., 612 F.2d 604 (2d Cir. 1979), cert. dismissed, 448 U.S. 914 (1980), Judge Friendly, characterizing an agreement to establish a dual-rate system in the print advertising industry as a concerted refusal to deal rather than price fixing, advised the district court on remand to examine the reasonableness of the practice. 612 F.2d at 618 n.23. The per se rule creates a temptation for judges to classify conduct as something other than price fixing-such as an information exchange or a refusal to deal-in order to avoid a harsh result. See Note, supra note 111, at 722-25. The rule of reason for tacit price-fixing conspiracies must be recognized formally by the courts in order to allow practitioners to prepare and present evidence adequately. This would both promote judicial economy and provide a more certain, though a more searching, standard by which business practices are tested. 
the self-interest of each firm, were it acting alone, then shifts to the defendants. The plaintiff has the ultimate burden of showing that no defendant would have engaged in the parallel conduct unless all did. ${ }^{132}$ If the plaintiff-successfully meets this burden, tacit agreement is not proved but is a permissible inference for the trier of fact. ${ }^{133}$

Under the second prong of the test-the rule-of-reason inquiry-courts may find useful analogies to conduct examined under section 2 of the Sherman Act, ${ }^{134}$ which, like this phase of the analysis, also focuses on finding adverse market effects rather than evidence of collusion. For example, if the defendants collectively do not have market power, even a formal agreement would be unsuccessful in affecting the market price. ${ }^{135}$

Recent decisions arising out of litigation in two industries-southern plywood and lead anti-knock compounds for gasoline-show that some courts have begun to move toward such a two-step approach. These decisions also illustrate the merits of the approach and the inadequacy of the alternatives.

In Boise Cascade Corp. v. FTC, ${ }^{136}$ the Federal Trade Commission challenged the defendant plywood producers" use of a "West Coast freight factor" in setting plywood prices. This factor was used in establishing a "delivered zone price" that consisted of two elements, an "index price" and freight; the "delivered zone price" was uniform throughout an entire geographic zone. ${ }^{137}$ Using a system adopted from the more established West Coast plywood industry, the southern plywood producers calculated the freight ele-

${ }^{132}$ See Weit v. Continental Ill. Nat'l Bank \& Trust Co., 641 F.2d 457, 460-61 (7th Cir. 1981), cert. denied, 455 U.S. 988 (1982).

133 The inference is strengthened if the "participants are many and if they comprise a non-oligopolistic industry, where the economic pressures forcing action and reaction with competitors are absent." Delaware Valley Marine Supply Co. v. American Tobacco Co., 297 F.2d 199, 203 (3d Cir. 1961), cert. denied, 369 U.S. 839 (1962).

134 Courts have frequently analogized sections 1 and 2. See Mid-Texas Communications Sys. v. American Tel. \& Tel. Co., 615 F.2d 1372, 1389 n.13 (5th Cir.) ("It is clear . . . that the analysis under section 2 is similar to that under section 1 regardless whether the rule of reason label is applied per se."), cert. denied, 449 U.S. 912 (1980); see also California Computer Prods., Inc. v. International Business Machs. Corp., 613 F.2d 727, 735 (9th Cir. 1979) ("The defendant's acts [in a $\$ 2$ monopolization claim] are properly analyzed analogously to contracts, combinations and conspiracies under $\$ 1$ of the Sherman Act."). But see Copperweld Corp. v. Independence Tube Corp., 104 S. Ct. 2731, 2740 (1984) ("Concerted activity subject to $\S 1$ is judged more sternly than unilateral activity under $\S 2 . ")$.

13s See Board of Regents v. NCAA, 707 F.2d 1147, 1157 (10th Cir. 1983), aff'd, 104 S. Ct. 2948 (1984).

${ }^{136} 637$ F.2d 573 (9th Cir. 1980).

137 Id. at 573-74. 
ment of each delivered price according to the cost of shipping the plywood by rail from the West Coast, although it was actually shipped by truck from the southern production points. ${ }^{138}$

The Ninth Circuit held that these practices violated neither section 5 of the FTCA nor, by analogy, section 1 of the Sherman Act. ${ }^{139}$ The court found no evidence in the record that such delivered pricing had an anticompetitive effect, ${ }^{140}$ noting that the FTC had cited no evidence to disprove the "common sense proposition" that southern producers continued to adjust the total price-by varying the index price-to reflect locational or other trade advantages. ${ }^{141}$ The court concluded that the "bare existence of an industry-wide artificial freight factor" was not a section 5 violation because it was not "utilized, tacitly or overtly, to match prices and avoid price competition." "i42 Even if agreement could be inferred from parallel conduct, the Ninth Circuit reasoned, it must be shown that "the challenged pricing system has actually had the effect of fixing or stabilizing prices. . . . [P] arallel behavior, without more, does not trigger the per se treatment which is given to overt agreement."143

Although the Ninth Circuit did not reach the issue of whether there was an agreement among the defendants, it did assert the need in such cases to look "for at least tacit agreement to use a formula which has the effect of fixing prices."144 Thus, the court's analytical framework is precisely that of the two-step approach advocated here: there must be evidence of a tacit agreement, and there must be evidence of anticompetitive conduct. ${ }^{145}$

198 Id. at 577-78.

130 Id. at 581.

$140 \mathrm{Id}$.

${ }^{141} I d$. at 579-80 ("[T]he existence of substantial bargaining in the base price of plywood provides at least a prima facie inference that competition has not been affected by the use of West Coast freight. The Commission has proved no substantial evidence to rebut that inference.").

142 Id. at $576-77,581$.

${ }^{143}$ Id. at $577-81$.

141 Id. at 576.

${ }^{145}$ In In re Plywood Antitrust Litig., 655 F.2d 627 (5th Cir. 1981), cert. dismissed sub nom. Lyman Lamb v. Weyerhauser, 462 U.S. 1125 (1983), the Fifth Circuit held that this same parallel practice "plus the numerous items of direct evidence of communication between high-level personnel on pricing policy" were sufficient for the jury to find a pricefixing conspiracy. 655 F.2d at 634 . The jury had found that the plaintiffs were damaged by this practice because "west coast freight" exceeded actual freight charges from southern shipping points. Id. at 631-32. The trial court did not allow the producers to raise the business-justifications defense, see Brief of Petitioners Weyerhauser Company and Willamette Industries, Inc. at 43-44, Lyman Lamb, and the Fifth Circuit affirmed the trial court's jury instructions, $655 \mathrm{~F} .2 \mathrm{~d}$ at $637-38$. 
If the court had applied the business-justifications test alone, it might well have arrived at a different conclusion. The defendants may not have been persuasive in asserting reasons for the use of West Coast freight consistent with their independent selfinterest. The Ninth Circuit noted that the plywood producers had urged buyer preference as a business justification: the use of the West Coast price index promoted "ready price comparison between western and southern plywood."146 In discussing this assertion, however, the court sounded a note of skepticism by stating that "plywood middlemen [who used the quoting system] arguably would have little stake in an artificially imposed but uniform addition to price that could readily be passed on to the [ultimate] consumer."147 The court's discussion demonstrates that, without ruleof-reason analysis in addition to the business-justifications test, the southern plywood pricing practice might have been condemned even though the evidence suggested that it did not impair competition.

In contrast, the rule-of-reason inquiry by itself would have condemned, and the business-justifications test by itself would have exonerated, parallel practices involving the lead anti-knock compound market. In E.I. Du Pont de Nemours \& Co. v. FTC, ${ }^{148}$ the FTC had condemned three practices employed by the only four producers of lead anti-knock gasoline additive: (1) the sale of the product by all four firms at a delivered price that included transportation costs; (2) the giving of extra advance notice of price increases by two of the producers, over and above the thirty days provided by contract; and (3) the use by three of the producers of a "most favored nation" clause under which the seller promised that no customer would be charged a higher price than other customers. ${ }^{148}$ The Second Circuit vacated the FTC's order and found

146 637 F.2d at 578. For an economic discussion of delivered pricing in light of the plywood cases, see Carlton, supra note 129.

${ }^{147} 637$ F.2d at 580. This skepticism is well founded. The plywood producers claimed that the use of West Coast freight made price comparison easier for the purchaser who, knowing that the freight element of the delivered price would be identical whether shipped from the West or the South, would simply need to compare the index prices quoted by the various producers. Id. at 574 n.1. Even this system is cumbersome, however, when compared with a delivered-price system where a consumer is quoted the price of a product delivered to the doorstep. After all, the consumer is interested in relative final prices, including product price and delivery costs. Under such a system, found in several industries, see Carlton, supra note 129, at 52-53, there is no need for the consumer to do any calculations to determine relative final prices. It seems unlikely that the "index plus West Coast freight" pricing system would remain were one firm to price plywood in this greatly simplified form.

148729 F.2d 128 (2d Cir. 1984).

149 The FTC's opinion, In re Ethyl Corp., 101 F.T.C. 425, 592 (1983), is summarized by 
that these practices did not violate section 5 of the FTCA. ${ }^{150}$

The FTC did not claim that these practices were the result of any express or tacit agreement. Instead, it relied solely on a ruleof-reason analysis that, as the FTC noted, is similar to the approaches advocated by Posner and Turner. ${ }^{151}$ The FTC had reasoned that section 5 could be violated "even in the absence of agreement if the firms engage in interdependent conduct that, because of the market structure and conditions, facilitates price coordination in a way that substantially lessens competition in the industry." 152

The Second Circuit found, however, that each producer had legitimate, independent business reasons for the challenged practices. ${ }^{153}$ Moreover, it denied that the FTC had power to condemn practices by oligopolists, even under section 5 , without some showing of tacit agreement, evidence of anticompetitive intent or purpose, or the absence of independent and legitimate business reasons for the conduct. ${ }^{154}$

The court stated that the FTC's rule-of-reason approach to oligopoly pricing left the law "in a state of complete unpredictability." 155 A business would be required to review constantly not only its own conduct, but also the conduct of competitors and the reaction of each to the other-all in an effort to avoid conduct that cumulatively leads to supracompetitive prices. ${ }^{156}$ Instead, "[a] line must . . . be drawn between conduct that is anticompetitive and legitimate conduct that has an impact on competition."157

These two cases illustrate why it is inadequate either to apply the business-justifications test alone (with the implicit per se rule for practices that fail the test) or the rule-of-reason analysis alone (as suggested by Posner and Turner). The rule-of-reason inquiry fails because it makes no attempt to define the line "between con-

the Second Circuit in Du Pont, 729 F.2d at 130. The industry was a "natural oligopoly," exhibiting high concentration, small likelihood of new entries because of a sharply declining market for leaded gasoline, inelastic demand, and homogeneity of the product. Id. at 132.

${ }^{280} 729$ F.2d at 141-42. As the Second Circuit explained, the FTC may enforce both the Sherman and Clayton Acts under section 5 of the FTCA. Id. at 136. Nevertheless, the FTC "is not confined to their letter. It may bar incipient violations of those statutes." Id.; see also FTC v. Brown Shoe Co., 384 U.S. 316, 321-22 (1966); FTC v. Motion Picture Advertising Serv. Co., 344 U.S. 392, 394-95 (1953).

${ }^{161}$ In re Ethyl Corp., 101 F.T.C. 425, 599-602 (1983).

162729 F.2d at 135.

${ }^{163}$ Id. at $134-35,140$.

134 Id. at 139-40.

188 Id. at 139.

${ }^{38}$ Id.

167 Id. at $137-38$. 
duct that is anticompetitive and legitimate conduct that has an impact on competition." The business-justifications test draws the line, but by itself does not determine whether the conduct has the requisite "impact on competition." These issues can only be properly addressed by applying both the conduct-oriented business-justifications test and the impact-oriented rule-of-reason inquiry.

\section{Conclusion}

Section 1 of the Sherman Antitrust Act requires both concerted action and restraint of trade before a challenged business practice becomes unlawful. Because parallel conduct cannot properly be treated as per se anticompetitive, the courts' application of the business-justifications test to parallel conduct without a ruleof-reason inquiry for anticompetitive effects is contrary to the purpose of section 1 of the Sherman Act and to the Supreme Court's decision in Broadcast Music. Conversely, the approaches of Posner and Turner, which focus solely on anticompetitive effects, expose firms to liability for conduct that would not violate section $1 \mathrm{ab}$ sent its interaction with the conduct of other competitors. Courts examining parallel conduct under section 1 should require a showing both that there is an agreement among competitors and that the challenged conduct has an anticompetitive impact on the market.

Michael K. Vaska 